\title{
Development and Its Challenges in Nigeria: A Theoretical Discourse
}

\author{
Benyin Akomaye Adah ${ }^{1}$ \\ Ugochukwu David Abasilim²
}

\author{
1 University of Uyo, Uyo, Akwa Ibom State, Nigeria, Department of Political Science and \\ Public Administration, bibianaadah@yahoo.com \\ ${ }^{2}$ Covenant University, Ota, Ogun State, Nigeria, Department of Political Science and \\ International Relations ugochukwu.abasilim@covenantuniversity.edu.ng
}

\section{Doi:10.5901/mjss.2015.v6n6s2p275}

\begin{abstract}
Development is said to be a predictor that determines whether a country is progressing or not. A critical assessment of Nigeria's development despite her abundance in human, natural and material resources reveals that the country is yet to achieve the desired expectations as clamored by her citizens. The objective of this study was to identify the challenges to development in Nigeria. In order to obtain data for the research, the work adopted qualitative research method through textual analysis. The findings of this study revealed that despite the country's attempt to advance development, several challenges has posed a great threat to her progress. These setbacks range from imposition of policies on her citizens, lack of adequate human resources or capital to implement development plans/policies, corruption and lack of credible leadership among others. The paper concludes that once the identified setbacks are tackled then development will be realized in the country.
\end{abstract}

Keywords: Citizen, Corruption, Development, Human Resources, Leadership

\section{Introduction}

The personal worth of any national government is the attainment of qualitative level of development as it is a crucial aspect of any nation's drive to self-reliance. Lawal (2011) posited that development is a vital necessity to the growth and sustentation of any vibrant nation. Thus, for development to be ensured, socio-political and economic stability must be guaranteed at all levels of government as this will promote citizens natural attachment to the governing process. In as much as development is vital to any nation's progress, Okereke \& Ekpe (2002) observed that there has been an unequal level of development in the world and this has precipitated numerous scholarly debates and postulations explaining why some countries are more developed than others.

Nigeria like most African countries is highly endowed with both human and natural resources, as well as rich in cultural heritage. Various administrations in Nigeria had during the past presented and attempted comprehensive plans which were geared towards achieving development in the state. These plans encapsulated programmes that were to enhance the general welfare of the citizens and the nation at large. In fact, development and growth has been government's top priorities since the attainment of independence. This is because development planning can be seen as the only avenue where the allocation and utilization of resources can be adequately handled (Ibietan \& Ekhosuehi, 2013).

According to Ogunmike (1995), the first practical plan for development in Nigeria was in 1946, having as its specific objective, fostering economic growth and improving the general welfare of its citizens. The development plan which however reflected the independent status of Nigeria was introduced in 1962 and was operational for a period of six years. The plan aimed at maintaining and improving the growth of its Gross Domestic Product (GDP) by depending heavily on multi-lateral aids, 50 percent of its total investment was to come from abroad. The first development plan abruptly came to an end as a result of the collapse of the first republic and the subsequent eruption of the civil war. In addition, out of the 50 percent of foreign aid which were expected, only about 14 percent were received, thus leading to the inability to achieve the identified objectives (Ogunmike, 1995). After the civil war, the second development plan was launched spanning from 1970 to 1974. The second plan for national development came at a period when Nigeria's sale of crude oil and other products were at an increase. The plan had its priorities anchored on agriculture, industry, transportation, man power, defence, electricity, communication, water supply and provision of social services. The plan also aimed at restructuring the nation that had suffered from post war violence. The third plans for development which spanned from1975 to 1980 was considered more ambiguous as emphasis was on rural development and agriculture. 
Suffice to note these policies all aimed at generating government's revenue, reducing the need for importing foreign products, bringing income inequality to a minimum level, as well as controlling inflation. The plan succeeded in indigenizing the economy, established free education and other industrial projects. There was an increase in the GDP rate, while the manufacturing, building and construction sectors were also not left out in the transformation process (Ogunmike, 1995). The fourth development plan was also established, followed by the Structural Adjustment Programme (SAP), all with the aim of restructuring and diversifying the economy, achieving a stable fiscal and balance of payments over a stipulated period, laying foundation for non-inflationary growth and enhancing the possible growth of the private sector. Other national development plans such as National Economic Empowerment Development Strategy (NEEDS), Seven Point Agenda and the Transformation Agenda have also been launched in recent times, as a response to the development challenges of Nigeria and a national plan for prosperity (National Planning Commission, 2004).

Despite all the development plans by the Nigerian government, a lot of setbacks has been encountered in the developmental process. According to Osakwe (2010) the nature of Nigeria's development strategy has contributed to the slow pace in achieving poverty and unemployment reduction in the country, as such, the country has not gone through the normal process of structural transformation. This implies that the strategies employed by Nigeria government has not led to the growth of productive capacities and structural transformation which are the pivot for generating any productive employment opportunities and reducing poverty to a minimal level. Thus, the efforts made by various governments has not been worthwhile as unemployment, poverty and inequality is still on the increase.

According to Ibietan \& Ekhosuehi (2013), the lack of coordination and harmonization of programs/policies both within the tenure of an administration and those succeeding it has been the impediment to development. In line with the above, the argument of this paper is that despite all efforts by Nigerian government to achieve development, why has it been difficult for its attainment, which can be visibly appreciated and undeniable by her citizens or better still what are the challenges to development in Nigeria? It is therefore against this background that this paper intends to carefully examine what development entails, some theories of development and the challenges to development in Nigeria, while also proffering possible solutions through its recommendations.

\section{Concept of Development}

The ambiguous nature of development has made it difficult to advance a precise meaning. In fact there are numerous perspectives as to what the concept of development is all about. There is the perspective that sees it from the economic perspectives, while others sees it as a concept that is multidimensional, meaning that development is beyond the economic domain. According to Meier (1988), development is the act of raising to the highest value the Gross National Product through the process of accumulating capital and industrialization. Development can also be viewed as the capacity of a nation to increase its static economy to a level where it can generate and sustain an annual increase in its Gross National Product (GNP). Additionally, he further stated that development is not limited to just the process of acquiring industries, but encompasses such processes as modernization, productivity, social and economic equalization, modern technical know-how, improved institutions, and attitudes as well as rationally coordinated policy apparatus (Meier, 1988). In the same light, Oghator \& Okoobo (2000) pointed out that development goes beyond the increase in per-capita income or economic growth, but also includes sustainable improvements in the living standard of the people, which is guaranteed through the provision of gainful employment, coupled with the presence and availability of social and economic infrastructures.

On the other hand, Seers (1979) defined development by posing certain questions such as; what has been happening to poverty, unemployment and inequality. To him, if all three indices (poverty, unemployment and inequality) are at a relatively high rate, there is absence of development, and vice versa. It follows therefore that for a country to be classified as developed, there are parameters to look out for which are: the state of poverty, unemployment and inequality. For Todaro (1985), buttressing on the multi-dimensional nature of the concept of development opines that it is the re-organisation and re-orientation of the entire economic and social system. Ajagun (2003) corroborates that development is a state of advancement which makes life more meaningful in its various aspects, including the economic, administrative, political, social, cultural and religious aspects. This implies that development is not about a particular aspect but it is encompassing, better still multi-dimensional depending on the point of contention. According to Onah (2005), development is not static but is a continuous improvement in the capacity of the individual and society to control and manipulate the forces of nature for the enhancement of the living standard of the people in a society. This definition introduces another dimension to the meaning of development, it analyses the human aspect of development, that is, the individuals who resides in a given state. Ahmed (2007) also noted that development is concerned with the general upliftment in the material, social and psychological conditions of a given human society. 
Adamolekun (2007) also stressed that development has to do with improving the living condition of people. He highlighted some indicators of development, which includes; a higher quality of life, higher income, better education, higher standards of health and nutrition, less poverty in society, a cleaner environment, more equal opportunities, greater individual freedom and richer cultural life amongst citizens of a given state. From the various meanings of development outlined, it can be deduced that development is not limited to economic growth or per capita income alone but is a concept that is all encompassing that analyses the economic, administrative, political, social, cultural, religious, and living standard of the people in a given society.

\section{Theories of Development}

Development theories consist of various theories which has been propounded to explain how desirable change in the society is best achieved. The following theories therefore serves as a base for understanding the concept of development.

$$
\begin{array}{ll}
\text { - } & \text { Modernisation theory } \\
\text { - } & \text { Dependency theory } \\
\text { - } & \text { World system theory } \\
\text { - } & \text { Globalisation theory }
\end{array}
$$

\subsection{Modernization Theory}

Modernization theory is an economic theory rooted in capitalism which evolved in the 1950s and 1960s. Modernization is a comprehensive theory which deals with the whole process a nation encounters in its attempts of transforming from a primitive to a modernized society. Modernization consists of a gradual process of specialization and separation of social structures, with the aim of promoting efficiency in the developmental process of any society. According to Roxborough (1979), modernization theory operates on economic oriented principles which posits that capital formation and investment are the major determinants of economic growth and development.

Within the theory of modernization is the stage model which views development as a process which passes through various evolutionary phases. According to Ollawa (1981) the main focus of stage model is that development follows certain stipulated framework, as such, nations who seek to achieve economic growth must adhere to this framework. The most prominent scholar of the stage model is W.W. Rostow. For Rostow (1962), development is divided into five stages which are; the traditional society, the pre-condition for take-off stage, the take-off stage, the maturity stage, and the stage of high-mass consumption.

The traditional stage is an agrarian society that is not aware of its capability to transform its society to a modern community. They are therefore not willing to take advantage of the potential of modern science and technology (Okereke \& Ekpe, 2002). At the stage of precondition for take-off, the society becomes aware of its transformation potential and in turn gets involved in the application of modern science and technology to agricultural and industrial practices. The opportunity for investment and commerce therefore increases at this stage. The take-off stage places emphasis on the eradication of traditional obstacles which hinders economic growth and development. At this stage, the commercialization of agriculture is introduced and investment rises to a maximum level. The drive to maturity stage is a period when the economy shows the capacity to extend beyond the original industries that served as its pivot for take-off. The final stage of development is that of high mass consumption, it focuses on the production of durable consumer goods and services which is marked by a rise in real income (Okere \& Ekpe, 2002). Implicit in the stage model is the assumption that some countries are developed because of their strict adherence to this evolutionary developmental process. The //psychological//diosyncratic theory is also another strand in modernization theory which attributes development to certain attitudinal personality variables. It is assumed that it is the innovative personality of a nation that stimulates economic growth and development (Okereke \& Ekpe, 2002).

Just like most theories, the theory of modernization has also encountered various criticisms. The stage model of modernization has been criticized on the basis that development does not follow strictly a particular motion. Thirwall (1985) argues that the stage theory establishes a rigid platform for development and also creates an impression that a nation can attain industrialization only when the agricultural sector has been modernized. His argument revolves on the fact that both agriculture and industries are to grow alongside each other if maximum development is to be achieved. The psychological theory of modernization has been criticized for being psychologically reductionist. It is argued that the theory employs psychological concepts to explain purely sociological problems (Okereke \& Ekpe, 2002). 


\subsection{Dependency Theory}

Dependency theory originated in Latin America during the 1960s basically as an alternative to the modernization theory. The theory operates on the notion that some countries experience development because these countries exploit the natural and human resources of smaller countries to boost their economy, establishing a centre-periphery relationship. According to Enoh (2009), the periphery countries are compelled to provide natural resources, labour, and markets for the developed countries at a relatively cheap rate in exchange for capitals and loans. This gradually leads to a state of perpetual dependency through multifaceted relationships between the two groups of countries.

The argument therefore is that development is absent in some countries because of inadequate capital, unfavourable climatic conditions, inferior cultural heritage and absence of motivation. Okereke \& Ekpe (2002) maintain that dependency theory represents the complex relationships that bind the advanced countries of the centre and the backward counstries of the periphery. They are also of the view that dependency theory of development is a kind of parasitic relationship existing between the highly industrialized countries and the less developed countries, established in a manner that will ensure the continuous advancement of the industrialized countries to the detriment of the less developed ones. According to Uche (1994), dependency theory predominantly deals with two actors in the international system who continuously are characterized with one form of unequal relationship or another.

Dependency theory has been criticized by free market economists. They argue that by promoting the establishment of state-owned companies, the theory encourages the growth of corruption since state-owned companies have a higher rate of corruption than private-owned companies. It is also argued that by subsidizing indigenous industries and eliminating external importation of products, there will be lack of competition as these industries may lack incentives to improve their products.

\subsection{World-System Theory}

World system theory as propounded by Immanuel Wallenstein has its foundation on the dependency theory. World System is a social system, comprising of identifiable boundaries, structures, individual groups, prescribed rules, and coherence. The theory suggest that there is an economic system in the world which aids the development of some countries at the expense of others (Uche, 1994). Development according to the World system theory can be analysed based on three hierarchical levels which are; Core, Periphery, and Semi-periphery countries.

The Core countries are predominantly capitalist countries who are economically powerful, possess strong military power and are not dependent on any state or country for their survival. The periphery countries are made up of nations who are weak, lack strong economic base and central government. Their weaknesses provides an avenue of exploitation and manipulation. The peripheral countries lack the basic technological facilities to boost their economy, as such, they export their raw materials to the core countries at a relatively cheap rate and in turn import finished goods at a highly exorbitant price.

These countries depend solely on the capital given to them by the core countries for their economic survival. The semi-peripheral nations fall between the two groups, as such, they share the characteristics of both the core and peripheral countries. The semi-peripheral countries are those who employ various strategies such as industrialization and economic diversification to improve their economic status. They are sometimes exploited by the core countries, but are not subject to perpetual manipulations and exploitation like the peripheral countries. In fact, they sometimes exploit the peripheral countries.

The central thesis of the world system theory is that development is achieved as a result of the exploitation of one country by the other. The development of any nation is therefore predetermined by the role it plays and the class it belongs in the world economy. The world system theory has however been criticized for being too focused on the economy. It has also been criticized for bridging the boundary between the state and big businesses.

\subsection{Globalization theory}

Globalization theory is established on a perspective which is quite similar to the world system theory, however its main focus is on the cultural aspect of nations and their international communications. Globalization theory argues that development can be analysed based on the cultural links which exists among nations in the international community (Kaplan, 1992). According to Reyes (2001), the central premise of Globalization theory is that development can be understood by analysing the international connections, primary roles, and interconnected relationships which exist among various nations in the international community. The theory argues that an increasing degree of interconnection and 
integration among nations plays an important role in achieving any atom of development. Reyes (2001) pointed out that globalization theory lays emphasis on the cultural aspects of nations and their interactions among each other, as such, development can best be interpreted along cultural and economic linkages existing among nations.

According to Moore (1993), globalization theory ensures that global communication system is gaining momentum in many parts of the world, thereby creating opportunity for underdeveloped nations to communicate with the developed nations through modern technology. The increase in communication among nations is creating an enabling environment for business transactions which could eventually boost development. Globalization theory therefore views cultural factors and communication network as the main determinants of economic progress in any nation.

Globalization theory has been criticized for being an uneven process as it does not always stimulate economic progress of all nations as expected. Okereke \& Ekpe (2002) maintain that globalization has brought about cultural inferiority among African nations.

The above mentioned theories tends to analyse development in Nigeria from various perspectives. The Modernization theory for instance argues on the fact that Nigeria's poor state of development may be linked to her inability to adhere to the various stages of development as prescribed by Rostow. In addition, evidence also reveals that the innovative personality of the Nigerian state may as well have an adverse effects on the nation's efforts to achieve adequate development since its innovative capacity is still at a rudimentary stage.

The dependency theory on the other hand tends to attribute Nigeria's poor state of development to the economic exploitation from the more powerful and industrialized countries of the world. This is because there has always been an unequal trade relationship between the developed and developing countries of the world. Thus, this theory is of the view that for development to be achieved, independent nations must strive to establish state owned industries that will aid in boosting its economy towards self-reliance.

Development challenges in Nigeria according to the World system theory can be attributed to the division of various countries into three hierarchical levels which are; Core, Periphery, and Semi-periphery countries. Development can therefore be achieved by the continuous exploitation of one country by the other. Thus, development tends to favour only those countries that possess adequate capital and technical know-how which other countries can depend on that have a greater advantage in the world market system. Globalization theory also argues that development in Nigeria can be achieved and sustained when there is an increasing level of cultural and social interactions with other countries of the world. This is because the high level of global communication, integration and interconnection will aid in the transfer of ideas, technologies and capital among the industrialized and developing countries of the world.

\section{Challenges of Development in Nigeria/Possible Solution}

Studies have shown that there are numerous factors that challenges development in Nigeria (Makinde, 2005; Babawale, 2007; Nnabuife, 2010; Yunusa, 2009; Itah, 2012; Gberevbie, Shodipo \& Oviasogie, 2013). For Makinde (2005), he maintains that the imposition of policies on citizens of a nation, lack of adequate human resources or capital to implement these plans/policies, corruption and lack of credible leadership are the major challenges to Nigeria's development. Most national development problems in Nigeria arises as a result of poor implementation of policies and subsequently lack of adequate and reliable human resources. Makinde (2005) further maintained that most policies of developing nations are imposed on the masses. The policies are made by the government without considering the target population, as such the masses are not given the opportunity to contribute in the formulation of policies that concern their wellbeing. In addition, there are no human resources or capital to implement these plans as a result of the low quality of human development in the country. Records from United Nations Development Programme 2014 report reveals that Nigeria ranked number 152 out of 187 countries in Human development, which is average quality of life and standard of living. The report puts Nigeria's Human Development Index at 0.381 which is below the prescribed level. Thus, in such instances, there is absence of continuity in policies when the tenures of specific governments come to an end. He also pointed that, although corruption is a global issue but Nigeria as a country is caught in the web of corruption. Often times, funds which are set aside for implementing policies are usually syphoned to the detriment of the entire nation. In addition, lack of credible leadership which can recognize and articulate the specific needs of the people also pose a challenge to development.

Dike (2010) also stressed the fact that leadership has become a bane to development in Nigeria. To him, most of the so called leaders do not actually understand that leadership entails assuming responsibilities for certain important issues. Poor governance on the part of the leaders has also resulted to inappropriate check and balances and mechanisms to regulate the affairs of government officials and institutions. As such, politics is seen as a "do or die" affair, while ethical politics is delegated to the background. The leadership structure in Nigeria is also said to be poor due to the 
inadequacies in accountability and transparency of public affairs managements in the nation (Gberevbie, Shodipo \& Oviasogie, 2013).

In addition, the improper assessment of policies implemented also serves as a challenge to development (Itah, 2012). Most policy makers fail to access the goal-achievement gap factor, implying that policy makers often times fail to access the level of achievements of certain implemented public policies. The reason for this is because most leaders present policies which are too cumbersome and difficult to achieve within the short period spent in office. As such, most plans for national development are usually abandoned at the end of such tenures and subsequent governments also fail to continue on the plans which were left uncompleted. This therefore explains reasons for numerous abandoned projects found in these developing nations. Development has also been hindered by the numerous cases of poor management of public funds and also lack of accountability and transparency among others.

Adopting the globalization perspective, Nigerian leaders should study concretely the policy formulation process of other independent and sovereign states in the international system. They should ensure that the plans for national development should be people-centred. The masses should be involved at the formulation stage so as to put inputs on what concerns their lives and provide suggestions on how those inputs can be achieved. Political leaders should analyse concretely the goal achievement-gap so as not to present manifestoes that would not be realised during their stay in office. There should be continuity and stability in policies so as to avoid the continuous presence of numerous abandoned projects in Nigeria. Thus, Nigerian leadership must learn to build on already existing projects rather than to abandon them for new ones for the sake of political parties and other personal interests. Electoral processes in Nigeria should be reformed so as to promote a free and fair selections of leaders.

Local and developing industries should be encouraged by the government with all the necessary incentives to stimulate economic growth since they serve as the key to technological and industrial advancements of nation-states.

\section{Conclusion and Recommendations}

This paper has conceptually clarified the meaning of development and examined the challenges to development in Nigeria. These challenges range from the non-involvement of citizens in the formulation of policies, lack of adequate human resources or capital, corruption and lack of credible leadership among others.

The paper concludes that for development to be realised there is need to take care of the challenges mentioned and every other thing that may hinder the achievement of development in the country. It is pertinent to note that development is not one sided but multi-dimensional and also a continuum. It is on this premise that the following recommendations are made:

a. Government should put in more efforts in involving the masses in the formulation and implementation of policies. Policy makers are advised to adopt the bottom-up approach. This can be achieved through massive publicity of what they intend to do, what they are doing and what they will not do in regards to policy objectives.

b. There is also the need for government to take the anti-corruption campaign more seriously. That is to say, specific machineries such as the Economic and Financial Crimes Commission, Independent Corrupt Practices and Other Related Offences Commission be allowed to function more independently without any interference. In addition stiffer measures should be melted on any erring individual.

c. There is need for the emergence of new crop of leaders that are visionary centred, selfless, patriotic, accountable and transparent in all their dealings. In addition, Efforts should also be made by the Nigerian government to promote consistency in policies, as this will reduce the number of abandoned projects in the polity.

d. Accountability and transparency should be the country's guiding philosophy in all her operations.

\section{References}

Adamolekun, L. (2005). Governance Context and Re-orientation of Government. In: Adamolekun, L. (ed) Public Administration in Africa: Main Issues and Selected Country Studies. Ibadan: Spectrum Books Limited, pp.3-16.

Ahmed, H. (2007). Strategies for Accelerated Rural and Community Development at Local Government Level. The Nigerian Journal of Administrative Studies, 5(3): 64-77.

Ajagun, S. O. (2003). The Significance of Culture on Human Development in Nigeria. International Journal of Governance and Development, 1 (20):107-116.

Babawale, T. (2007). Good Governance, Democracy and Democratic Best Practices: Prescriptions for Nigeria. Lagos: Centre for Black and African Arts and Civilization Publications Monograph Series. pp. 7-16. 
Dike, V. E. (2011). Revising Instrumental Leadership Problem in Nigeria. Ibadan: Ibadan University Press.

Gberevbie, D. E., Shodipo, A. O. \& Oviasogie, F. (2013). Leadership and Accountability: The Challenges of Development in Nigeria. Thought and Practice: A Journal of the Philosophical Association of Kenya, 5 (1): 121-140.

Ibietan, J. \& Ekhosuehi, O. (2013). Trends in Development Planning in Nigeria: 1962 to 2012. Journal of Sustainable Development in Africa, 15 (4): 297-311.

Itah, J. O. (2012). Democracy and Good Governance: Nigeria's Dilemma. African Journal of Political Science and International Relations. 4 (6).

Lawal, O. O. (2011). Democratic Corruption, Good Governance and Development: The Prospect and Challenges of Institution building in Nigeria. A paper presented at the IPSA mid-term international Conference in Abuja.

Makinde, T. (2005). Problems of Policy Implementation in developing nations: The Nigerian Experience. Journal of Social Science, 11 (1): 63-69.

Meier, K. J. (1988). The Political Economy of Regulation: The case of Insurance. New York: Suny Press.

Nnabuife, E. K. N. (2010). Defining and Enforcing Ethical Leadership in Nigeria. African Journal of Economics and Management Studies. 1 (1): 25-41.

Oghator, E. \& Okoobo, R. (2000). Towards Sustainable Development in less Developed Countries: Foreign Assistance Revisited. The Nigerian Journal of Administrative Science, 5 (10): 201-208.

Ogunmike, F. (1995). The Effect of Macro Level Government Policies in Rural Development and Poverty Alleviation in Nigeria. Ibadan Journal of Social Sciences, 1: 15-24.

Okereke, O. O. and Ekpe, A. E. (2002). Development and Underdevelopment: Politics of North South Divide. Enugu: John Jacob's Classic Publisher Ltd.

Onah, V. C. (2005). Democratic Governance and Crisis of Development in Nigeria. American Journal of International Politics and Development Studies, 1 (1): 129-137.

Osakwe, R. N. (2010). Education for People with Special Needs in Nigeria: Challenges and Way Forward. In M. I. Atinmo, J. B. Babalola, O. A. Moronkola and A. I. Atanda. (Eds). Education for Sustainable Development. Faculty of Education, University of Ibadan. 3343.

Seers, D. (1979). The Meaning of Development, with a postscript. In D. Lehmann (ed). Development Theory: Four critical studies. New York: Routledge.

Rostow, W. W. (1962), "The Stages of Economic Growth" London: Cambridge University Press, pp. 2, 38, 59

Todaro, M. P. (1979). Economics for Developing Nations. London: Longman Group Limited.

Yunusa, M. (2009). Democratic Governance and Leadership in Nigeria: An Appraisal of the Challenges. Lapai International Journal of Management and Social Sciences, 2 (1):166-172. 